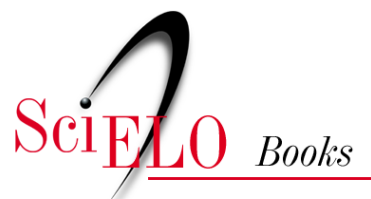

\title{
Apresentação Introduction
}

Simone Petraglia Kropf

Aline Lopes de Lacerda

Diane Grosklaus Whitty (trad.)

\section{SciELO Books / SciELO Livros / SciELO Libros}

KROPF, S.P., and LACERDA, A.L. Apresentação = Introduction. In: Carlos Chagas, um cientista do Brasil = Carlos Chagas, scientist of Brazil [online]. Translated by Diane Grosklaus Whitty. Rio de Janeiro: Editora FIOCRUZ, 2009, pp. 11-14. ISBN: 978-65-5708-000-9. https://doi.org/10.7476/9786557080009.0002.

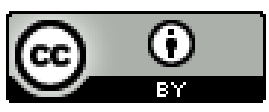

All the contents of this work, except where otherwise noted, is licensed under a Creative Commons Attribution 4.0 International license.

Todo o conteúdo deste trabalho, exceto quando houver ressalva, é publicado sob a licença Creative Commons Atribição 4.0. 


\section{Apresentação}

Carlos Chagas, um cientista do Brasil integra o conjunto de iniciativas empreendidas pela Fundação Oswaldo Cruz (Fiocruz), em 2009, para a comemoração do primeiro centenário da descoberta da doença de Chagas. Em abril de 1909, o mineiro Carlos Chagas (1878-1934), médico e pesquisador do Instituto Oswaldo Cruz (IOC), comunicou ao mundo científico a descoberta de uma nova doença humana. Seu agente causal (o protozoário que denominou de Trypanosoma cruzi, em homenagem a Oswaldo Cruz) e o inseto que o transmitia (triatomíneo conhecido como barbeiro) também haviam sido por ele identificados, ao final de 1908. A 'tripla' descoberta viria a constituir-se em um marco na história da ciência e da saúde no Brasil.

Representando uma contribuição inovadora ao campo da medicina tropical, Chagas traria a público não apenas uma nova enfermidade humana, mas a realidade sanitária e social do interior do país, assolado pelas endemias rurais. Enaltecida como uma das glórias do IOC, a descoberta conferiu imediato prestígio e projeção ao jovem cientista, que receberia várias distinções acadêmicas no Brasil e no exterior, tendo sido indicado ao Prêmio Nobel de Medicina por duas vezes.

A trajetória de Carlos Chagas foi muito além dos créditos que adquiriu por descobrir a doença que leva seu nome. Como sucessor de Oswaldo Cruz na direção do IOC (1917-1934), ampliou as fronteiras da instituição, consolidando-a como renomado centro de produção, pesquisa e ensino no campo da medicina experimental. Como diretor dos serviços federais de saúde pública do país (19191926), estendeu a ação do Estado brasileiro ao interior, promovendo importantes ações de saneamento rural e a formação de profissionais especificamente treinados para a área de saúde pública. No ensino médico, teve destacada atuação como professor da cadeira de medicina tropical da Faculdade de Medicina da Universidade do Rio de Janeiro. Defendeu a importância da pesquisa para a formação profissional dos médicos e afirmou que a associação entre o laboratório e a clínica era o caminho para que as novas gerações enfrentassem o desafio de estudar e combater as "doenças do Brasil", que atingiam, sobretudo, a população pobre das áreas rurais.

Identificando, na enfermidade que ele próprio descrevera, um dos grandes "flagelos" dos sertões brasileiros - que comprometia a vitalidade de seus trabalhadores e, conseqüentemente, o "progresso" da nação -, Carlos Chagas foi pioneiro da campanha em prol do saneamento rural do Brasil, que teve como legado a ampliação da intervenção do Estado na saúde e, sobretudo, o diagnóstico de que o atraso do país era fruto das doenças que o assolavam, profundamente associadas às más condições de vida no interior. Protagonizando importantes momentos e processos pelos quais a ciência e a saúde pública brasileiras se institucionalizavam como campos de conhecimento e de intervenção social, Chagas materializou, em sua trajetória, o projeto de uma ciência afinada com os avanços do conhecimento no cenário internacional e, ao mesmo tempo, comprometida em revelar os problemas da sociedade brasileira e indicar os caminhos para enfrentá-los.

O presente livro apresenta a trajetória biográfica de Carlos Chagas por meio, fundamentalmente, de imagens. São tanto fotografias como representações visuais de outras naturezas, como charges, caricaturas, desenhos, ilustrações científicas, e vêm acompanhadas de documentos textuais (cartas, anotações de pesquisa, matérias de jornal, publicações, diplomas) e museológicos. Nosso intuito é gerar uma composição múltipla que forneça ao leitor uma compilação dos mais expressivos documentos relativos à vida e à obra deste importante cientista. Tais registros foram selecionados, sobretudo, no vasto acervo da Casa de Oswaldo Cruz (COC), mas também em conjuntos arquivísticos de outras instituições, no Rio de Janeiro, Minas Gerais e São Paulo.

$\mathrm{O}$ arquivo pessoal de Carlos Chagas, sob a guarda da COC, expressa as múltiplas dimensões dessa trajetória que associou, de modo estreito, ciência, saúde pública e projetos/debates sobre a nação, e que, ao fazê-lo, gerou expressivos impactos não apenas no campo da medicina, mas também no universo cultural mais amplo da sociedade brasileira. Trata-se de um precioso material para historiadores e pesquisadores que busquem informações sobre a organização e a institucionalização da ciência e da saúde brasileiras em sua inserção na vida social do país e no ambiente internacional da época.

Carlos Chagas, um cientista do Brasil é composto de capítulos que abrangem: sua infância, sua formação médica, as campanhas que realizou contra a malária, a descoberta da doença que leva seu nome, os estudos sobre este assunto, a polêmica em torno da nova enfermidade, a expedição que realizou à Amazônia, sua atuação como diretor do IOC e como gestor da saúde pública federal, sua atividade como professor, alguns aspectos de sua vida pessoal e familiar e, por fim, premiações e títulos que conquistou ao longo de sua carreira. Ao início de cada capítulo, um pequeno texto apresenta os conteúdos históricos fundamentais sobre cada tema e convida o leitor a percorrê-lo através da narrativa das imagens.

Gostaríamos de agradecer àqueles que, de diversas maneiras, contribuíram para a realização deste livro. Antes de tudo, à Casa de Oswaldo Cruz, pelo amplo apoio que proporcionou à concretização do projeto, que reúne duas áreas de grande importância na 
instituição: a pesquisa em história das ciências e da saúde e a pesquisa no campo da documentação, esta associada ao trabalho de organização dos acervos arquivísticos.

A João Canossa, um registro igualmente especial: mais do que editor, ele foi um colaborador decisivo nas várias etapas de elaboração deste livro. Destacamos também nosso agradecimento aos auxiliares de pesquisa que colaboraram de modo decisivo para este trabalho, com minucioso e amplo levantamento de fontes. A Luis Octavio Gomes de Souza, que, além desse levantamento, colaborou de modo sistemático em todo o processo de elaboração do livro, desde sua concepção até a redação e revisão dos textos que o compõem, nosso reconhecimento especial. Além do trabalho de qualidade que o distingue como pesquisador, ele nos proporcionou uma agradável companhia, tornando-se, ao longo desta jornada, um querido amigo.

Deyse Pimenta Cacau, historiadora mineira, apoiou-nos na busca de documentos nos arquivos do estado natal de Carlos Chagas. Demian Bezerra de Mello, além do auxílio à pesquisa, contribuiu com a obtenção da necessária autorização para o uso das imagens aqui reunidas. A Cleice de Souza Menezes, Luciana Pinheiro, Marcela Thimoteo, Danielle Barreto e Francisco Lourenço, somos gratas pela disponibilidade em colaborar conosco em função das atividades que vinham realizando para outros projetos da COC relacionados ao centenário da descoberta da doença de Chagas, como a organização do Arquivo Carlos Chagas e a atualização da Biblioteca Virtual Carlos Chagas.

De grande importância foi o trabalho de digitalização das imagens realizado pelos fotógrafos Roberto Jesus Oscar e Vinicius Pequeno, companheiros de longa data na COC, que sempre estiveram a postos para atender nossas inúmeras solicitações, muitas vezes sob a pressão dos prazos, mas sempre com a gentileza e a eficiência que os caracterizam. A Rose Oliveira e Jean Maciel, tão importantes na missão institucional em disponibilizar a consulta pública dos documentos que integram nossos arquivos, também somos gratas pela presteza em responder às nossas demandas. Ao pesquisador Gilberto Hochman, agradecemos a leitura crítica e as sugestões que ajudaram a aprimorar o texto.

O Arquivo Carlos Chagas, que forneceu a parte mais substancial das imagens aqui publicadas (algumas delas inéditas), é resultado do empenho carinhoso e sistemático de Carlos Chagas Filho em reunir os 'papéis' de seu pai e da generosidade de doar à Casa de Oswaldo Cruz material tão precioso. Esse belo e louvável compromisso em preservar e divulgar a memória do cientista foi compartilhado por sua esposa, Anna Leopoldina de Mello Franco Chagas, que, após o falecimento de Carlos Chagas Filho em 2000, prosseguiu enviando ao nosso Departamento de Arquivo e Documentação novas remessas de documentos. Durante o processo de elaboração deste volume, contamos com a colaboração preciosa da neta de Carlos Chagas, Cristina Chagas Gouvêa Vieira, a quem manifestamos nosso agradecimento. É para nós uma grande satisfação que este livro traga, assim, de distintas maneiras, a marca da colaboração da família Chagas.

E, a propósito do acervo de Carlos Chagas, registramos nosso agradecimento a Renata Borges, que coordenou a equipe de organização desse arquivo na Casa de Oswaldo Cruz, por ter aceitado o convite para colaborar conosco com um texto sobre esse processo de organização, realizado também como parte das comemorações do centenário da descoberta da doença de Chagas.

Contar a história de Carlos Chagas, em sua múltipla atuação como pesquisador, professor e gestor, com base em imagens e outros tipos de registros, foi um desafio e um enorme prazer. Foi um processo marcado por escolhas difíceis, diante da diversidade de documentos com os quais nos deparamos, e também por lacunas inescapáveis. Foi também pontuado por momentos muito particulares, como este, que deixamos aqui registrado.

Ao pesquisar o precioso arquivo do médico Belisário Penna, responsável pelas ações de saneamento rural durante a gestão de Carlos Chagas no Departamento Nacional de Saúde Pública, pudemos perceber, nas centenas de registros fotográficos produzidos nos vários estados brasileiros, a dimensão concreta do projeto sanitarista que mobilizou esses e tantos outros médicos, cientistas e intelectuais nas primeiras décadas do século XX. E qual não foi nossa surpresa quando, entre os muitos habitantes daquelas longínquas paragens brasileiras, uma de nós (Simone) deparou-se com a imagem de sua tia-bisavó, Jandira Caldas Botelho, no balcão de um posto sanitário na pequena Quebrangulo, interior de Alagoas.

Além da extraordinária coincidência, o episódio teve um sentido que vai além de seu aspecto pitoresco e nos levou a pensar em uma importante dimensão do legado de Carlos Chagas. Essa ciência que alcançou projeção internacional e ao mesmo tempo se embrenhou pelos 'sertões' do Brasil, na trilha de Euclides da Cunha, produziu não apenas idéias e intervenções sobre a nação, mas o registro histórico de muitos brasileiros e brasileiras anônimos, gente simples e comum, sobre a qual provavelmente não haveria indícios nos arquivos correntes dos grandes centros. Junto aos tantos doentes fotografados pelo olhar médico, a expressar a triste realidade de um Brasil "imenso hospital", estiveram os muitos trabalhadores - médicos, enfermeiras, farmacêuticos - que se associaram aos médicos e cientistas vindos do 'litoral' nesse longo e coletivo processo pelo qual a medicina brasileira construiu não apenas conhecimentos e ações de saúde, mas a própria nação. Nos arquivos, e nas imagens que eles guardam, encontramos fragmentos e vestígios desse caminho. Que o leitor tenha prazer em percorrê-lo conosco. 


\section{Introduction}

Carlos Chagas, scientist of Brazil is one of several initiatives undertaken by the Oswaldo Cruz Foundation (Fiocruz) in 2009 as part of the centennial celebration of the discovery of Chagas disease. In April 1909, Minas Gerais native son Carlos Chagas (18781934), physician and Oswaldo Cruz Institute (OCI) researcher, announced to the scientific world that he had discovered a new human disease. At the end of 1908, he had also identified its causative agent (a protozoan that Chagas called Trypanosoma cruzi, in honor of Oswaldo Cruz) and the insect that transmitted the sickness (a triatomine known as the barbeiro, or barber bug). This triple discovery became a landmark in the history of science and health in Brazil.

When Chagas made this innovative contribution to the field of tropical medicine, he revealed to the public not only a new human illness but also the sanitary and social reality of Brazil's hinterlands, beset by rural endemic diseases. Lauded as one of the triumphs of the OCI, the discovery won the young Brazilian scientist immediate prominence and prestige and would earn him numerous academic awards at home and abroad, including two nominations for the Nobel Prize in Medicine.

Carlos Chagas's accomplishments went far beyond the discovery of the disease that bears his name. As Oswaldo Cruz's successor as head of the OCI (1917-1934), he expanded the Institute's borders and secured its position as a well-regarded center of production, research, and teaching in the field of experimental medicine. As director of Brazil's federal public health services (1919-1926), he extended the government's reach into the interior of the country by setting in motion important rural sanitation actions and training specialized public health personnel. In medical education, he had a notable role as chair of tropical medicine at the University of Rio de Janeiro's School of Medicine. He was a strong advocate of making research an integral part of a physician's training and believed that tying the laboratory to clinical practice was the key to ensuring that new generations could meet the challenge of studying and combating the "diseases of Brazil," whose prime victims were the poor people of rural areas.

Carlos Chagas saw the illness that he was the first to describe as one of the great "scourges" of the Brazilian hinterlands, compromising its workers' vitality and therefore the "progress" of the nation. He was a pioneer of the Brazilian rural sanitation movement, whose legacies included increased government intervention in the health field and, chiefly, the diagnosis that Brazilian backwardness stemmed from the diseases afflicting the country, which were in turn intimately bound up with poor living conditions in the interior. As a protagonist of major events and processes in the institutionalization of Brazilian science and public health as fields of knowledge and of social intervention, Chagas brought to life a brand of science attuned to international advances in knowledge and simultaneously committed to laying bare the problems of Brazilian society and pointing the paths to their solution.

This book presents Carlos Chagas's biographical trajectory fundamentally through images-photographs and other kinds of visual representations, like cartoons, caricatures, drawings, and scientific illustrations-accompanied by museological and textual documents, that is, letters, research notes, newspaper articles, publications, diplomas. Our purpose was to provide our readers with a multifaceted composition that brings together the most illuminating records about this eminent scientist's life and work. These documents were selected principally from the vast holdings belonging to the Casa de Oswaldo Cruz (COC), while still others came from the archives of institutions in the states of Rio de Janeiro, Minas Gerais, and São Paulo.

Carlos Chagas's personal archive, in the custody of the COC, reflects the multiple dimensions of his life and career, which intertwined science, public health, and projects and debates about Brazil and thus had a significant impact not just in the field of medicine but in the larger cultural universe of Brazilian society as well. This particular set of records constitutes an invaluable resource for historians and researchers seeking information on the organization and institutionalization of Brazilian science and health and their interplay with the country's social life and the global context of the past.

The chapters of Carlos Chagas, scientist of Brazil explore the scientist's childhood, his medical education, the antimalarial campaigns he led, the discovery of the disease that bears his name, his research on the topic, the controversy engulfing the new illness, his participation in the Amazon expedition, his tenures as director of the OCI and as head of federal public health, his teaching activities, and elements of his personal and family life, closing with some of the awards and titles he garnered during his career. Each chapter begins with a short text offering some historical background on the topic, inviting the reader to learn more through the images that tell this story.

We would like to acknowledge the contributions of those who in a variety of ways have helped make this book possible. First and foremost, our thanks go to the Casa de Oswaldo Cruz for its broad support in bringing to life this project, which encompasses 
two vital areas of the institution: research in the history of the sciences and health and research in the field of documentation, along with the organization of archival holdings.

Our very special thanks as well to João Canossa. More than an editor, he was a decisive contributor at many moments in the preparation of this book. We would also like to thank our research assistants for their decisive collaboration and thorough, painstaking surveying of sources. In particular, Luis Octavio Gomes de Souza, on top of his specific research tasks, rendered ongoing assistance during the entire process, from the book's conception through the actual writing and editing, and for this we owe him special recognition. Besides the quality of his work, which sets him apart as a researcher, his company was a delight and in the course of this journey he became a dear friend.

Deyse Pimenta Cacau, historian from Minas Gerais, aided in our search for records held at archives in Carlos Chagas's home state. Demian Bezerra de Mello, in addition to providing research assistance, helped in obtaining authorization for the use of the images shown in these pages. Our thanks go as well to Cleice de Souza Menezes, Luciana Pinheiro, Marcela Thimoteo, Danielle Barreto, and Francisco Lourenço, who most obligingly collaborated with us as part of their involvement in other COC projects related to the centennial celebration of the discovery of Chagas disease, such as the organization of the Carlos Chagas archive and the updating of the Carlos Chagas Virtual Library.

Photographers Roberto Jesus Oscar and Vinicius Pequeno, longtime colleagues of ours at the COC, undertook the crucial task of digitizing the majority of the book's images; they were always willing to respond to our numerous requests with their characteristic unflagging kindness and efficiency, often under the pressure of an approaching deadline.

We would also like to thank Rose Oliveira and Jean Maciel, who perform such an essential role in the COC's mission to make the records in our archives available to the public for consultation and who were so accommodating in attending to our requests. Our further thanks go to the researcher Gilberto Hochman for his critical reading and suggestions that helped refine the text.

The Carlos Chagas archive, which furnished the bulk of the images found in these pages - some never published before - is fruit of Carlos Chagas Filho's careful, systematic endeavor to gather all his father's "papers" and then generously donate this invaluable material to the Casa de Oswaldo Cruz. This fine, laudable commitment to preserve and promote the scientist's memory was shared by Chagas Filho's wife, Anna Leopoldina de Mello Franco Chagas, who, following her husband's death in 2000, continued to forward new groups of records to our Department of Archives and Documentation. Throughout the preparation of this book, we benefited from the valuable collaboration of Carlos Chagas's granddaughter, Cristina Chagas Gouvêa Vieira, to whom we extend our gratitude. We take enormous satisfaction in the fact that this book bears the touch of the Chagas family, through their various forms of collaboration.

In regard to the Carlos Chagas holdings, we would like to thank Renata Borges, coordinator of the team responsible for organizing this archive at the COC, who kindly accepted our invitation to write a text about the organizing process, another component of this year's centennial celebration of the discovery of Chagas disease.

Telling the story of Carlos Chagas and his multifaceted career as researcher, professor, and administrator through images and others types of documents has been both a challenge and a joy. It was a process filled with tough decisions, given the diversity of records we faced, but also marked by inevitable gaps. We were rewarded with some very special moments, one of which we would like to share with you.

Our research took us into the valuable archive of physician Belisário Penna, responsible for rural sanitation measures while Carlos Chagas was head of the National Department of Public Health. Containing hundreds of photographic records taken at states around Brazil, this collection made us recognize the true dimensions of the sanitation project that mobilized these and so many other doctors, scientists, and intellectuals during the early decades of the twentieth century. And much to our surprise, among the pictures of so many inhabitants of far-flung corners of Brazil, one of us (Simone) stumbled on a photograph of her great-great-aunt Jandira Caldas Botelho, at the counter of a sanitary post in the small town of Quebrangulo, in rural Alagoas.

This striking coincidence set us to thinking beyond the incident's anecdotal charm and to reflecting about an important dimension of Carlos Chagas's legacy. This approach to science, which was projected onto the world stage at the same time that it ventured into the hinterlands of Brazil on the trail of Euclides da Cunha, did more than generate ideas and spur interventions with a nationwide impact; it also bequeathed us a historical record of many anonymous Brazilian men and women, simple, ordinary people who otherwise would be unlikely to leave any traces in today's big city archives. Among the scores of diseased people photographed by the medical eye, evincing the sad reality of the "enormous hospital" of Brazil, there were likewise many workers-physicians, nurses, pharmacists-who joined with the doctors and scientists from the seacoast as part of the long, collective process through which Brazilian medicine constructed new knowledge and new public health initiatives while building the very nation. In archives and the images they hold, we find fragments and traces of this road. We hope you will find pleasure in traveling it with us. 